\section{La luz en la obra de Le Corbusier}

Claudio Vásquez Profesor, Pontificia Universidad Católica de Chile

\section{Light in the work of Le Corbusier ${ }^{1}$}

Claudio Vásquez Professor, Pontificia Universidad Católica de Chile
A partir del análisis de una forma particular de concebir la luz natural en algunas viviendas proyectadas por Le Corbusier, se descubre la importancia que este arquitecto daba a la colocación de focos de iluminación artificial. Vanos, ventanas y componentes de fachada se combinan con el uso de ampolletas desnudas que caracterizan recintos y detalles.

LA ILUMINACIÓN DE LOS OBJETOS Y LOS OBJETOS PARA LA ILUMINACIÓN / La frase de Le Corbusier (1920) "la arquitectura es el juego sabio, correcto y magnífico de los volúmenes bajo la luz (...)" nos remite a sus imágenes de volúmenes platónicos, silos industriales y a su arquitectura de los años veinte. Sin embargo sería una banalidad buscar en ella la clave de su trabajo con la luz sin preguntarnos por las reglas de dicho juego y cómo buscó que fuera correcto y magnífico.

En la misma serie de artículos donde apareció esa frase, publicó un esquema de la Mezquita Verde de Bursa, visitada durante su viaje a oriente en 1911, para demostrar que la percepción del exterior es resultado del interior. El croquis hecho en el viaje es elocuente: de derecha a izquierda, una entrada de baja altura se abre a un volumen abovedado e iluminado cenitalmente que es flanqueado por otro similar, pero en penumbra, y por otro lateral de menor dimensión, también en sombra. Se trata de un vacío iluminado que funciona por el equilibrio que le dan las penumbras colindantes, una composición en base a la luz, pero también una secuencia que parte en la calle, continúa por un espacio pequeño y termina en un vacío, donde según Le Corbusier “(...) Uno se siente fascinado, pierde el sentido de la escala común (...)”. Luz y escala funcionan al unísono y se perciben porque existe una composición a través de los traspasos y del recorrido. Según él mismo explicó, estando en el interior se dimensiona el exterior. En la obra de Le Corbusier el trabajo de la luz tuvo este sentido compositivo -o de juego-, cuyas reglas pueden verse tanto en el uso de la luz natural como de la artificial.

OBJETOS ILUMINADOS O LA COMPOSICIÓN DE LA LUZ NATURAL / En 1925 Le Corbusier expuso su personal interpretación de la historia de la arquitectura de la ventana. Desde la penumbra del pequeño vano de la antigüedad, el primer salto fue dado por los vanos ojivales góticos, que iluminaban tanto como era posible. Posteriormente, el vano vertical del Renacimiento llegó al máximo tamaño si se considera el determinante debilitamiento de las estructuras murarías de la época. En los tiempos de Haussmann la ciudad comenzó a requerir fachadas más abiertas para rentabilizar el interior de los edificios, lo que forzó la ventana vertical a su máxima proximidad y planteó un problema que solo las estructuras porticadas de acero y hormigón pudieron resolver con la ventana longitudinal y la fachada completamente vidriada o pan de verre.

Para entender el cambio producido por la ventana horizontal, Le Corbusier presentó un esquema que compara las áreas de iluminación producidas por la misma superficie vidriada dispuesta en dos ventanas verticales y una horizontal de pared a pared. En base a mediciones fotométricas ${ }^{2}$, registró que las verticales generan hasta cuatro zonas con distintos niveles de iluminación mientras que la horizontal solo dos. Al analizar digitalmente los niveles de iluminación del esquema se comprueba que la diferencia efectivamente existe y que esta última produce una ilumina-
From the analysis of a particular way of understanding natural light in some of the houses by Le Corbusier, one discovers the importance given by the architect to the placement of points of artificial light. Openings, windows and facade components combine with the use of naked bulbs to give character to the spaces and details.
THE ILLUMINATION OF OBJECTS AND OBJECTS FOR ILLUMINATION / Le Corbusier's quote (1920) "architecture is the learned game, correct and magnificent, of forms assembled in the light. (...)" It sends us to his images of platonic volumes, industrial silos, and his architecture of the 1920's. However it would be useless to seek out the key to his work with light without asking for the rules and how he sought what was correct and magnificent.

In the same series of articles in which this quote appeared, a sketch of the Green Mosque in Bursa was published of his visit to the east in 1911 to demonstrate that the perception of the exterior is a result of the interior. The travel sketch is eloquent: from right to left, a low entrance opens onto a vaulted, naturally lit volume flanked by another, similar, but in shade and a smaller one on the other side, also in shade. The sketch illustrates a lit void that functions with the balance given by the adjacent shadows. A composition based on light but also on a sequence that begins in the street, continues through a small space and ends in a void where according to Le Corbusier "(...) one is fascinated, loses his sense of the common scale(...)". Light and scale work together and are perceived because of the existence of a composition of transitions and paths. He explained that being in the interior one gauges the exterior.

In the works of Le Corbusier the light has a compositional -or playful- sense whose rules can be seen in both his use of natural and artificial light.

OBJECTS ILLUMINATED OR THE COMPOSITION OF NATURAL LIGHT / In 1925 Le Corbusier exhibited his personal interpretation of the architectural history of the window. From the shadow of the small opening of antiquity, the first jump was made by the Gothic lancet windows that illuminated as much as possible. Later the vertical openings of the Renaissance arrived at their largest size considering the determining weaknesses of the structural walls of the time. In the age of Haussmann the city began to require more open facades to make the most of the interior of the buildings, forcing the vertical window to its maximum proximity, creating a problem that only portico-ed structures of steel and concrete could resolve with long window and the completely glazed facade or pan de verre.

To understand the change produced by the horizontal window, Le Corbusier presented a scheme that compared the illumination areas produced by the same glazed area placed in two vertical windows and a horizontal one, wall to wall. Using photometric measurements ${ }^{2}$, he recorded that the verticals generated up to four zones with with varying levels of illumination and the horizontal only two zones. By digitally analyzing the levels of illumination of the scheme we prove effectively that the difference exists and the horizontal window produces a more uniform light albeit with a strong difference between 
' Este artículo se basa en discusiones y resultados de trabajos realizados por los estudiantes Ignacio Pérez, Âlvaro Urrutia y Felipe Torreblanca, en cursos Seminario de Investigación de la Escuela de Arquitectura de la Pontificia Universidad Católica de Chile, realizados entre 2006 y 2008.
2 Estas mediciones son mencio-

nadas en diferentes textos, sin

embargo no hay registro de ellas,

salvo el croquis que se muestra.
This article is based on the results and discussions and work realized by the students Ignacio Pérez, Â-

varo Urrutia and Felipe Torreblanca, in the clases Investigation Semina at the Architecture school of the Pontificia Universidad Católica de Chile, between 2006 and 2008
2 These measurements are mentioned in arious texts, however there is no record of them apart from the sketch shown.

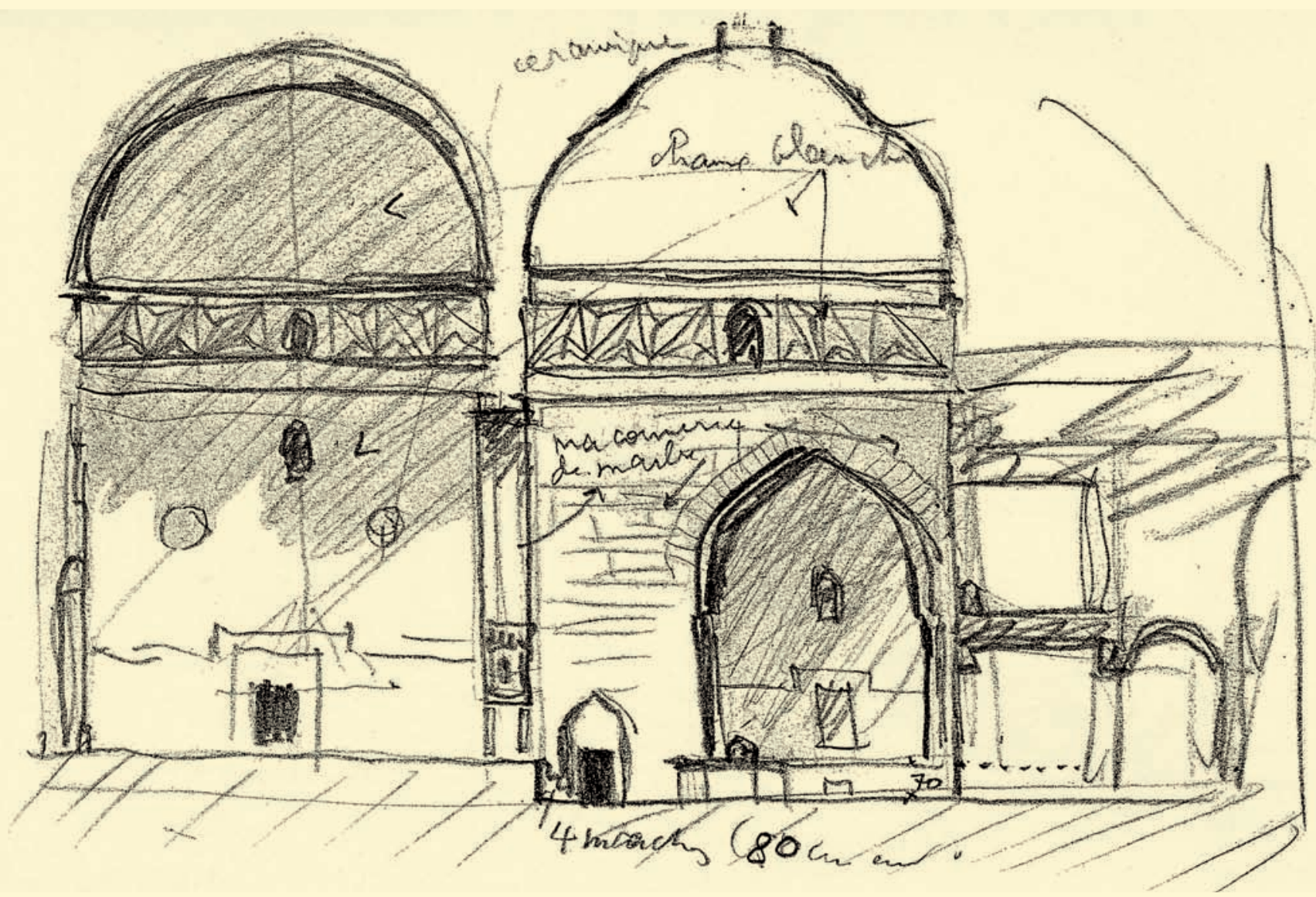

01 Le Corbusier, Croquis Mezquita Verde de Bursa, 1911. Fuente: Le Corbusier Mi Obra. Nueva Visión, Buenos Aires, 1960, p. 33 01 Le Corbusier, Sketch of the Green Mosque of Burs, 1911. Source: Le Corbusier. My work. New Vision, Buenos Aires, 1960, p. 33

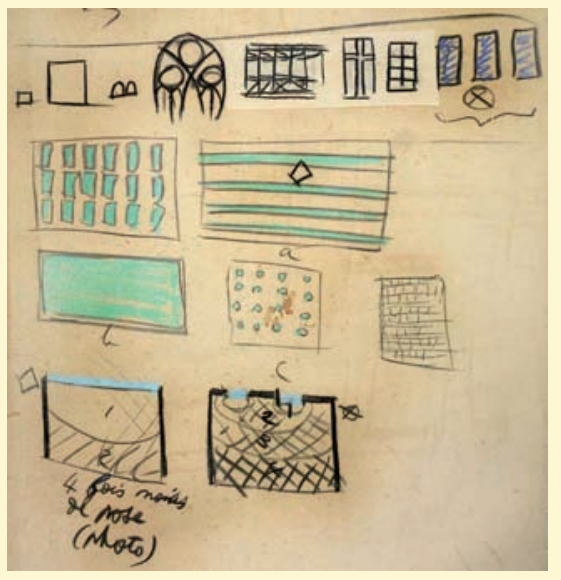

02 Le Corbusier. Esquemas de la historia de la ventana Fuente: recorte de lámina dibujada en Bs. As., 5 de octubre de 1929. () FLC 33522

02 le Corbusier Schemes of the history of windows.

Source: Clip of sheet drawn in Buenos Aires, 5 october 1929 (c) FLC 33522
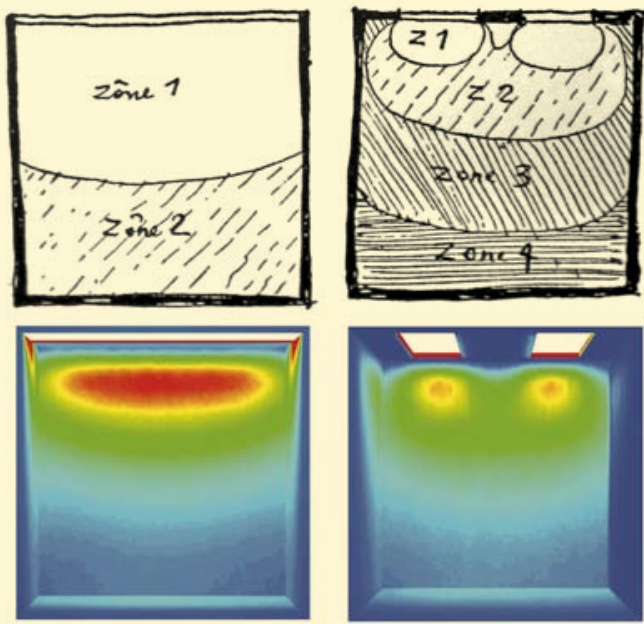

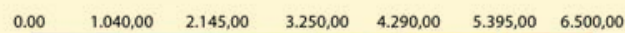
Intensidad luminica (lx)

3 Comparación entre ventana horizontal y vertical, según esquema de Le Corbusier y estudio modelado digitalmente. Fuente: estudio realizado por Âlvaro Urrutia en software 3dsmax V8.3, skylight overcast 8500 lux., 2006

03 Horizontal and vertical window comparison, according to scheme by Le Corbusier and digitally modeled study. Source: Study realized by Álvaro Urrutia in 3 dsmax V8 3 software, skylight overcast 8500 lux, 2006
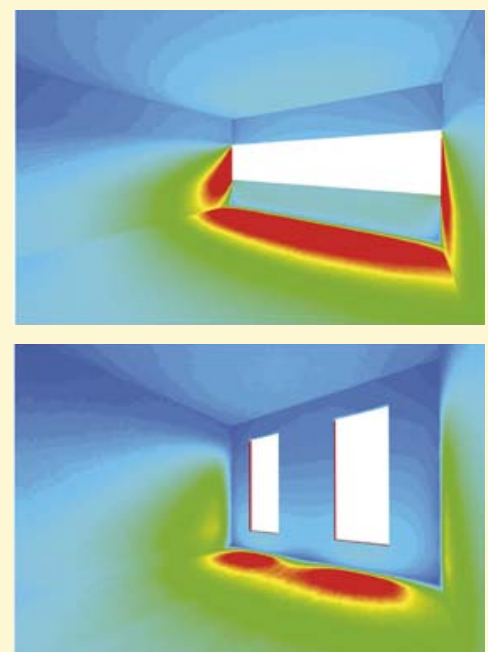

$640,00 \quad 1,320,00 \quad 2000,00 \quad 2600,00 \quad 3320,00 \quad 4,000,00$

Comparación entre ventana horizontal y vertical. Vista tridimensional. Fuente: estudio realizado por Álvaro Urrutia en software 3dsmax V8.3, skylight overcast 8500 lux., 2006 04 Horizontal and vertical window comparison. 3D view. Source: Study realized by Âlvaro Urrutia in 3dsmax V8.3 software, skylight overcast 8500 lux, 2006 

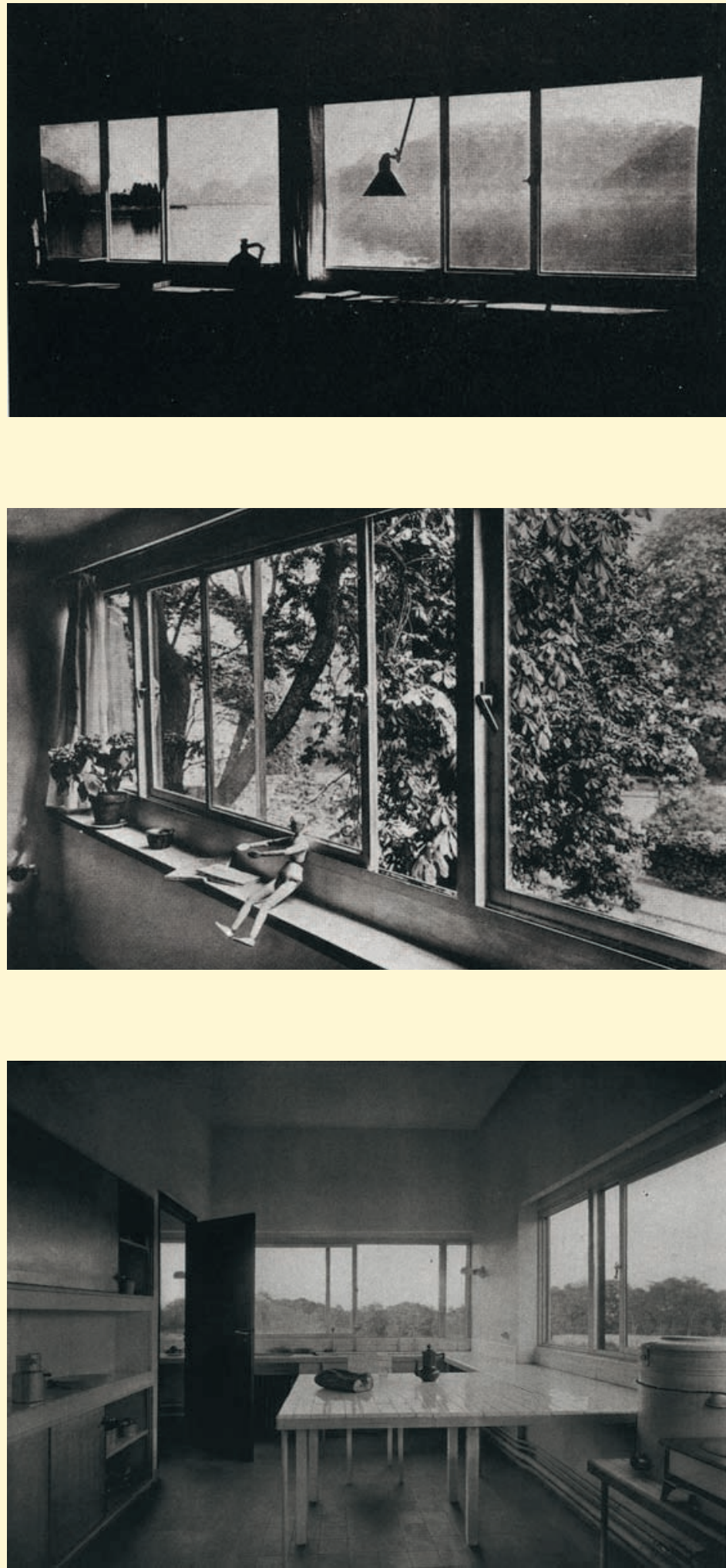

05 Fotografías de antepechos de la época.

De arriba hacia abajo: Une Petite Maison, 1923 / Maison Cook, 1926 / Ville Savoye, 1930 Fuente: L'Architecture vivante. París, otoño - invierno, 1925; otoño, 1927 y verano, 1931 05 Sill photographs of the time.

From top to bottom: Une Petite Maison, 1923 / Maison Cook, 1926 / Ville Savoye, 1930 Source: L'Architecture vivante. París, autumn-winter, 1925; autumn, 1927 and summer, 1931 ción más uniforme, aunque con una deslumbrante diferencia entre el frente y el fondo del recinto. El mismo análisis llevado a tres dimensiones permite observar que la ventana horizontal utiliza los muros laterales, el suelo y el cielo como reflectores que multiplican la eficiencia lumínica interior; por el contrario, las ventanas verticales no usan el cielo y los muros no llegan a las máximas intensidades.

La ventana horizontal formó parte de los cinco puntos de la nueva arquitectura, cuya principal importancia fue que abrieron una nueva "lírica compositiva" para el espacio gracias a que dieron plena libertad para diseñarlo. La terraza jardín, la ventana corrida, los pilotes, la ventana horizontal y la planta libre son elementos compositivos autónomos pero tecnológicamente tautológicos; todos hablan de lo mismo, esto es, el uso de estructuras de tracción activa. La promenade architecturale también fue parte de dicha lírica compositiva, ya que se activaba con la relación entre el cuerpo en movimiento y los objetos libremente dispuestos en el interior. Incluso la estructura, que se transformó en líneas de descarga, podía ser estratégicamente dispuesta como un objeto más.

La imaginería desarrollada en este ámbito transformó el mobiliario en un problema de arquitectura al incorporarlo como parte de la tabiquería. Una manera directa de entender esta relación fue registrada en una serie de dibujos con que Le Corbusier representó en 1925 la pequeña casa construida para sus padres a orillas del Lago Lemán, en Suiza. Las secciones y una serie de croquis muestran la asociación entre muebles y ventanas o entre tabiques y mobiliario, como elementos capaces de zonificar, conducir recorridos y también de iluminar una composición de elementos que configuran situaciones en que conviven la luz natural y los objetos dispuestos en el mobiliario.

Los antepechos de las ventanas horizontales se transformaron en portadores de los utensilios de la vida cotidiana. De hecho, fueron reiteradas las fotografias donde Le Corbusier registró este elemento en una ambientación cuidadosamente diseñada con todo tipo de objetos que, en silencio, hablan de la vida que transcurre en el recinto. Si se observa con detención, la repisa, la ventana y el antepecho configuran un sistema complejo. El dintel guarda la cortina; la ventana no llega a la altura de la repisa que remata el antepecho, sino más arriba; dicha repisa se confunde fácilmente con las mesas y abajo pueden aparecer muebles, redes o radiadores de calefacción. A esta densidad se suma otro elemento crucial: el paisaje y la máxima intensidad lumínica interior que se encuentra en el plano horizontal de la repisa del antepecho. En un mismo acto, objetos, luz y paisaje comparten un escenario que se arma con un contrapunto que pone en valor a los mismos objetos cotidianos que pintaba en la época. De esta manera, la iluminación natural remarca una composición que se basa en el contraste entre objeto y paisaje que lleva el uso de la luz natural a las bases de su pensamiento estético: la relación entre los objetos manufacturados y la naturaleza rectora de la acción humana.

Para entender cómo opera esta manera de componer con luz natural se puede observar un análisis de intensidad lumínica de la planta del segundo piso de la Ville Savoye. El rojo representa la máxima intensidad lumínica e inunda la terraza y el patio de servicio, que son a cielo abierto, pero además funciona como un anillo perimetral conformado por los antepechos de las ventanas horizontales, y a la vez arma una composición espacial en base al contrapunto entre objetos, luz y paisaje.

OBJETOS DESNUDOS O LA COMPOSICIÓN DE LA LUZ ARTIFICIAL / En 1925, Raoul La Roche escribió a Le Corbusier reclamando por la deficiente iluminación artificial de su casa, especialmente de la galería de cuadros ${ }^{3}$. En su carta reconoció que los artefactos diseñados eran ingeniosos, aunque insuficientes 
the front and the back of the space. The same analysis in three dimensions allows one to observe that the horizontal window utilizes the lateral walls, the floor and the ceiling as reflectors to multiply the interior light efficiency, while the vertical windows do not utilize the ceiling and the walls do not arrive at their maximum intensity.

The horizontal window formed part of the five points of the new architecture, whose principal importance was that they opened a new compositional poetry for space thanks to the liberty for design that it provided. The garden terrace, the ribbon window, the pilotis, the horizontal window and the open plan are autonomous, compositional elements and also technologically repetitive; all speak of the same, that is, the use of active tensile structures. The architectural promenade was also part of this compositional poetry in that it was activated by the relationship between the body in movement and the objects freely placed in the interior. Even the structure, that is transformed in load lines, can be strategically placed as an additional object.

The imagery developed in this environment transformed the furniture into an architectural dilemma, incorporating it as part of the walls. A direct way of understanding this relationship was through a drawing series that Le Corbusier exhibited in 1925, the small house built for his parents on the banks of the Leman Lake. The sections and a series of sketches show the association between furniture and windows or between walls and furniture, creating elements capable of zoning, creating paths as well as lighting a composition of elements that create situations where natural light and the objects within live together.

The sills of the horizontal windows are transformed into storage for the utensils of daily life. This was reiterated in the photographs where Le Corbusier recorded this element in an environment carefully designed with all kinds of objects that quietly speak of the life that takes places in this space. If we observe with care, the shelf, the window and the sill create a complex system. The lintel stores the curtain; the window doesn't reach the height of the shelf that finishes the sill; this shelf is easily confused with the tables under which appear furniture, connections or radiators. At this density another crucial element is added: the landscape and the highest intensity of interior light that is found on the horizontal plane of the sill-shelf. In one act, objects, light and landscape share a stage created by a counterpoint that places the everyday objects of the time in a place of importance. In this way the natural lighting emphasizes a composition based on the counterpoint between object and landscape, a contrast that employs natural light as the basis of an aesthetic thought: the relationship between manufactured objects and nature governing human action.

To understand how composing with natural light works, we can study an analysis of the luminosity of the second floor of the Ville Savoye. The red represents the maximum light intensity flooding the terrace and service patio open to the sky. It also functions as a perimetral ring formed by the ledges of the horizontal windows, creating a spatial composition based on the juxtaposition between objects, light and landscape.

NAKED OBJECTS IN THE COMPOSITION OF ARTIFICIAL LIGHT / In 1925, Raoul La Roche wrote Le Corbusier to complain about the lack of artificial light in his house, especially in the gallery ${ }^{3}$. In his letter, he recognized that the designed artifacts were ingenious although insufficient for lighting correctly. The photos of the time show that the solution consisted of a garland of naked light bulbs floating above the double-height space.

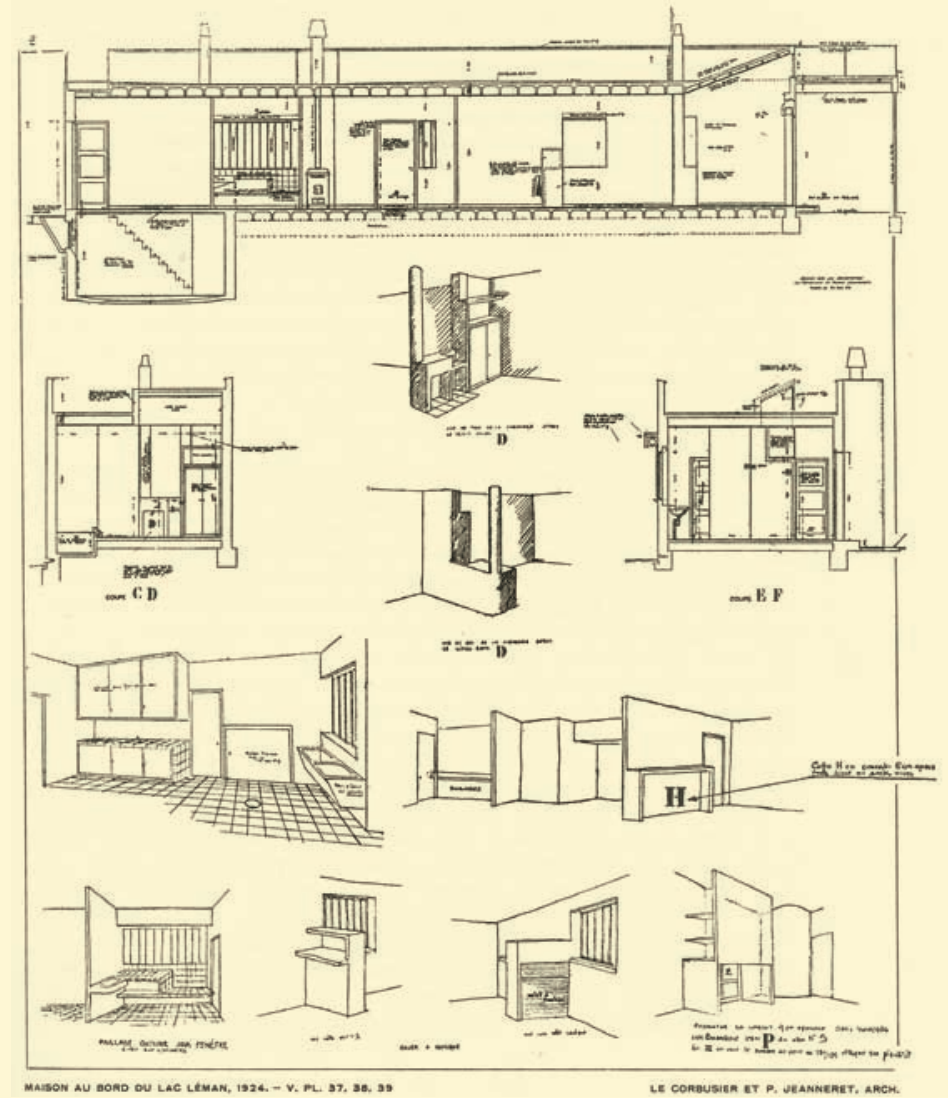

06 Le Corbusier. Une Petite Maison, Lac Léman, 1923. Fuente: L'Architecture vivante. París, automne \& hiver, 1925 06 Le Corbusier. Une Petite Maison, Lac Léman, 1923. Source: L'Architecture vivante. París, automne \& hiver, 1925

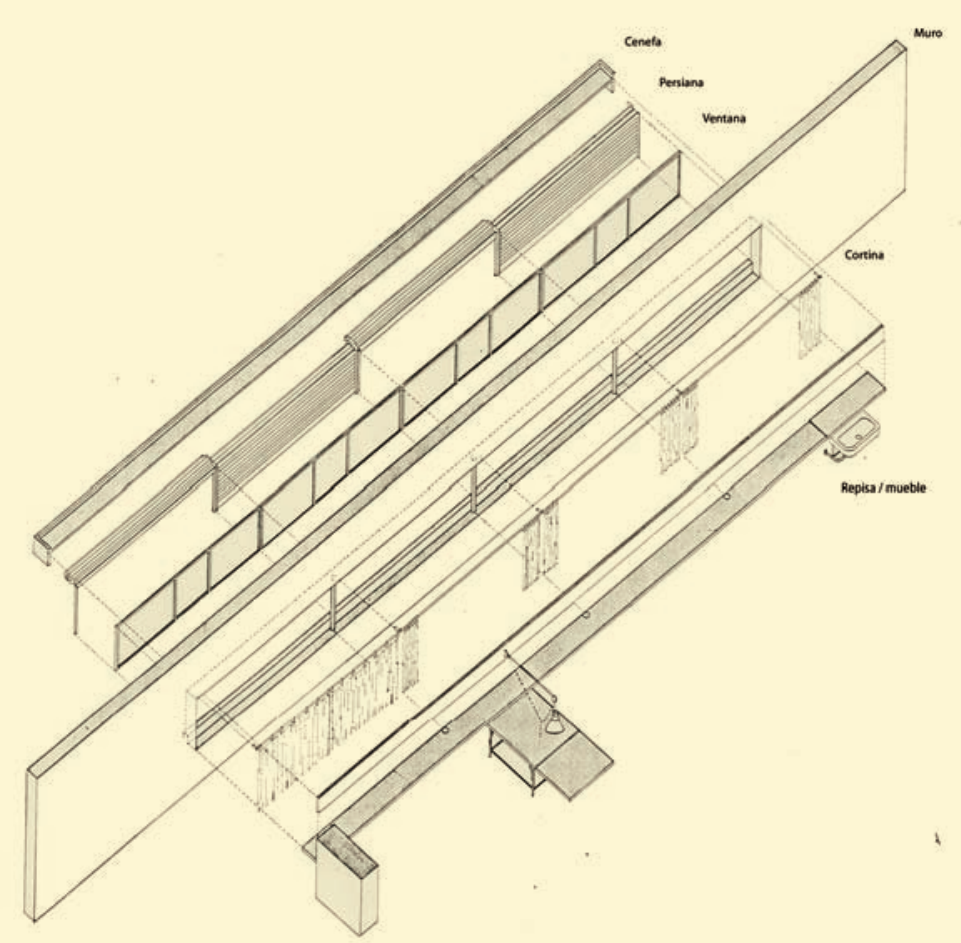

07 Ventana horizontal. Une Petite Maison, 1923. Fuente: dibujo del autor 07 Horizontal window. Une Petite Maison, 1923. Source: Drawing by the author 
4 Ver PERFECLA, Carta a Le Co busier. 27 de febrero de 1930, FLC H1-12-96
4 See PERFECLA, Letter to Le Corbusier. February 2, 1930, FLC H1-12-96. para iluminar correctamente. Las fotografías de la época muestran que la solución del arquitecto consistía en una guirnalda de ampolletas desnudas que flotaba en el espacio de doble altura. Sorprende que estos elementos no estén solo en fotografías de esta casa, también se observan en otras construidas en la década de los años veinte.

El control que Le Corbusier llevaba sobre la publicación de sus obras, sobretodo las fotografías, hace difícil considerar que las ampolletas desnudas estuvieran a la espera de una lámpara (De Smet, 2007). De hecho, en algunas de ellas, las ampolletas están encendidas de modo que su presencia no fuese desapercibida. Reafirma esta cuestión Reyner Banham (1969), quien notó el trabajo de fotomecánica realizado para reforzar la presencia de la ampolleta que ilumina la sala de estar de la Villa Cook (1926) en su publicación Oeuvre Complète. Por otra parte, tanto las especificaciones técnicas como la correspondencia asociada a diferentes obras dan cuenta de un acucioso control en la selección del cableado y de los artefactos utilizados. Por ejemplo en 1930 la casa PERFECLA $^{4}$ solicitó a Le Corbusier considerar algunos artefactos eléctricos que le habían gustado a Madame Savoye, demostrando que fue él quien los escogió para dicha obra.

Reyner Banham (1969) asoció el persistente uso de ampolletas desnudas en la casas puristas de los años veinte al prestigio declarado que adquirió la "honestidad absoluta" en diversos ámbitos de la producción artística e intelectual de la época, cuestión que es posible rastrear en diversos artículos de L'Esprit Nouveau. Además remarcó que si bien Le Corbusier utilizó una variedad de pantallas de vidrio y metal de origen industrial, el uso de ampolletas desnudas fue admisible por lo menos hasta 1930, considerando que igualmente se trataba de objetos industriales.

En 1928 la iluminación de la galería de la Villa La Roche fue cambiada por una sofisticada lámpara que alumbraba indirectamente el muro de cuadros, similar a la de la sala de la Ville Savoye. Esa estrategia de iluminación artificial que Flora Samuel (2007) ha seguido hasta el Carpenter Center de 1964 y que consiste en el uso de muros, cielos y suelos como superficies reflectantes activadas por lámparas cuidadosamente diseñadas para generar ambientes lumínicamente controlados. Estas lámparas fueron objetos de diseño especiales desarrollados a través de estudios y detalles que llevaban el trabajo de los arquitectos al detalle en escala 1:1. Fuera de este aspecto estético asociado a los objetos para iluminar, técnicamente la iluminación resultante puede ser evaluada de acuerdo a los estándares de la época, si se consideran los equipamientos y potencias especificadas en cada caso. En 1926, por ejemplo, Bolstroff aconsejaba lograr una iluminación horizontal con niveles de iluminación entre 15 y 20 lux para salas lujosas o principales, donde se desarrollaran actividades manuales; y entre 35 y 50 lux en talleres mecánicos, salas de conferencia y lugares afines. El análisis del taller de la Maison Ozenfant de 1922 y de la galería de la Maison La Roche de 1924 -ambas iluminadas con ampolletas desnudas- muestra que los estándares de la época se cumplen ya que tienen niveles medios de iluminación en torno a 55 lux, con una distribución que tiende a ser uniforme. El rendimiento en ambos casos está entre 9 y $11 \mathrm{w} / \mathrm{m}^{2}$, lo que muestra la aplicación de un criterio similar.

Es previsible que la coherencia con los estándares y la similitud de los
It is surprising that these elements are not only in the photos of this house, but also in other works of the twenties.

The control that Le Corbusier maintained over the publication of his works, especially over the photographs, makes it difficult to know whether the naked bulbs were waiting for a lamp (De Smet, 2007). In fact, in some of the photos the light bulbs are on, ensuring they do not go unnoticed. This reaffirms the question made by Reyner Banham (1969), who noted the photo-mechanical work done to reinforce the presence of the light bulb lighting the living room of the Villa Cook (1926) in his publication, Oeuvre Complète. On the other hand, in both the technical specifications and the correspondence associated with different projects reveal the detailed control of the selection of the cables and artifacts used. For example, in 1930 Perfecla House ${ }^{4}$ solicited Le Corbusier to consider some electrical artifacts that Madame Savoye had liked, showing that it was he who chose them for that project.

Reyner Banham (1969) associated the persistent use of naked bulbs in the purist houses of the twenties to the declared prestige of achieving the absolute honesty prevalent in various areas of artistic and intellectual production at the time, a concept that could be tracked in many articles of L'Esprit Nouveau. He also emphasized that Le Corbusier used a variety of glass and metal screens of industrial origin, and that the use of the naked bulb was admissible until at least 1930 considering that it also was considered an industrial object

In 1928, the illumination of the gallery in Villa La Roche was changed for a sophisticated lamp that indirectly lit the painting walls, similar to the lamp in the salon of the Villa Savoye (Fig.10), an artificial illumination strategy that Flora Samuel (2007) has followed up to the Carpenter Center in 1964. This strategy consists in the use of walls, ceilings and floors as reflective surfaces activated by lamps specially designed to generate controlled light environments. These lamps were special design objects developed through studies and details that took architects to the detail of 1:1 scale.

It was this aesthetic aspect associated with lighting objects, technically the resulting illumination that can be evaluated according to the standards of the time considering the equipment and potencies specified in each case.

In 1926, Bolstroff advised toward achieving a horizontal illumination with three light level between 15-20 lux for high-quality, or principal salons where manual activities are developed; and between $35-50$ lux for mechanical studios and conference rooms. The analysis of the studio of the Maison Ozenfant of 1922 and the gallery of the Maison La Roche of 1924, both lit with naked bulbs show that the standards of the time already met the requirements with light levels around 55 lux with an almost uniform distribution.

The output in both cases is between 9 and $11 \mathrm{w} / \mathrm{m} 2$, showing the application of similar criteria in both.

It is foreseeable that the coherence in the standards and the similarity of the output had nothing to do with the architects but with the techniques used in each case. In 1929 Le Corbusier made the 


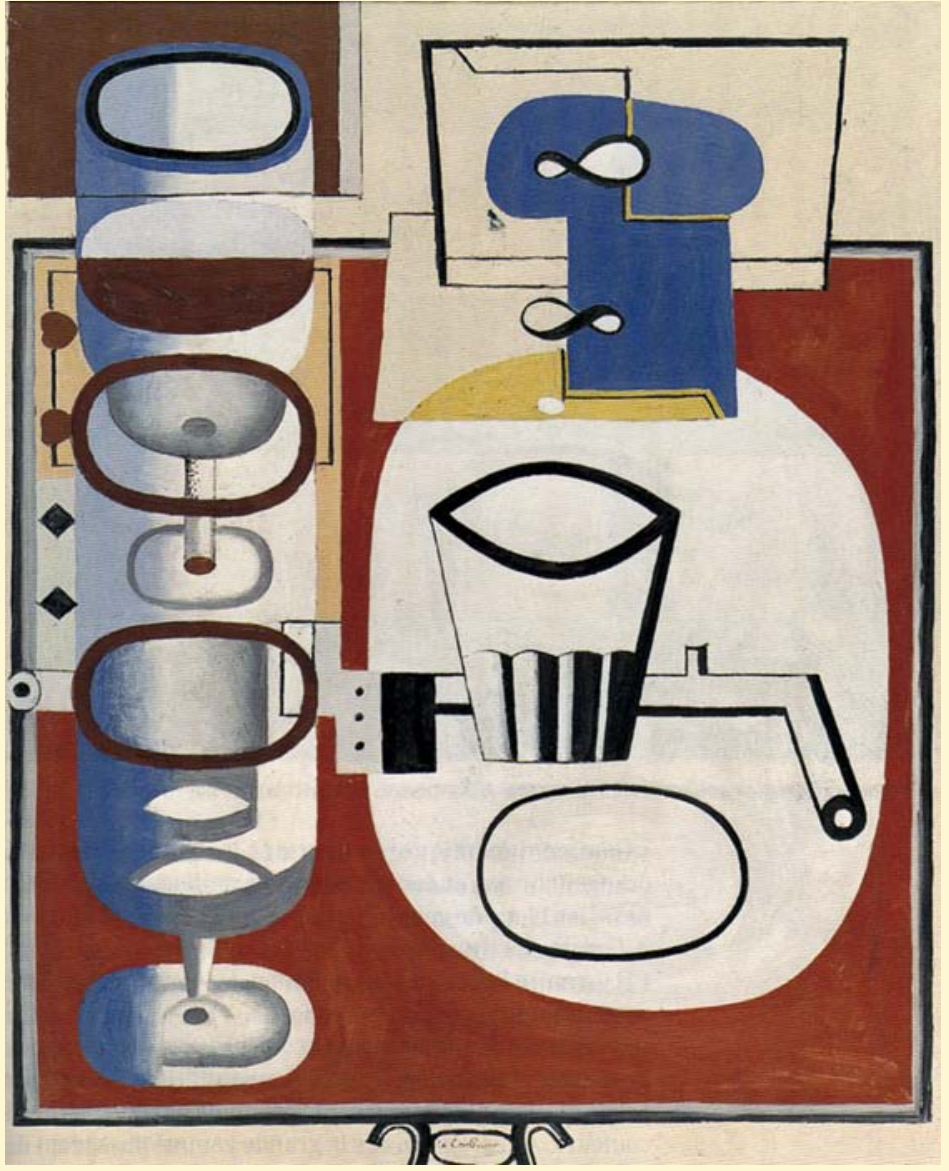

08 Le Corbusier, Machine abstraction, 1929. Óleo sobre tela. (C) FLC 172. Fuente: Le Corbusier. L' oeuvre Plastique. XI Rencontre de la Fondation Le Corbusier. Editions La Villete, París, 2005. p. 147

08 Le Corbusier Machine abstraction 1929. Oil on canvas. OFIC 172

Source: Le Corbusier. L'oeuvre Plastique. XII Rencontre de la Fondation Le Corbusier. Éditions La Villete, París, 2005. p. 147
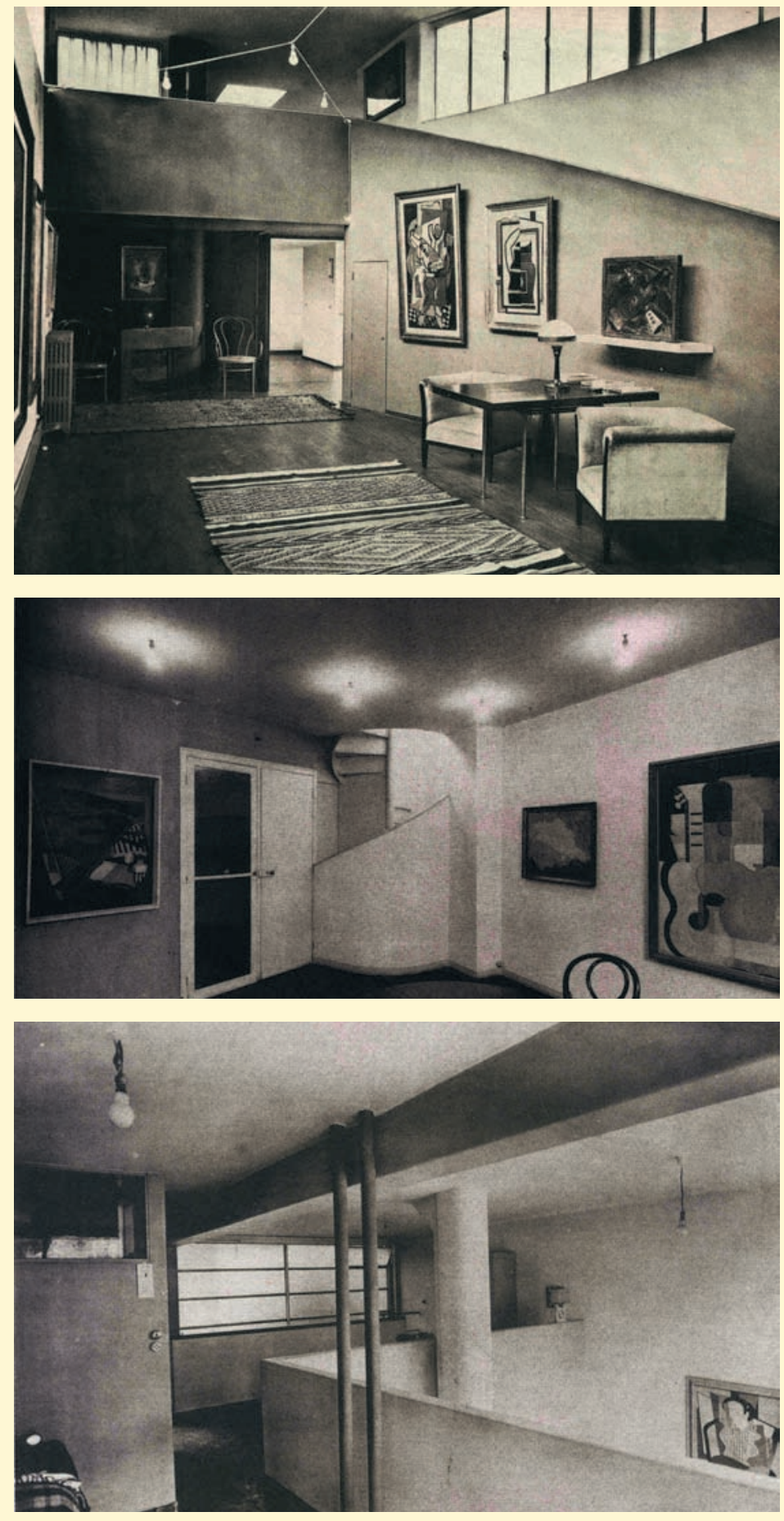

09 Ampolletas desnudas en distintas viviendas de la época. De arriba hacia abajo: Maison La Roche, 1923 / Maison Ozenfant, 1924 / Maison Planeix, 1927. Fuente: L'Architecture vivante, París, otoño, 1926; primavera, 1925 y primavera, 1930 09 Image of naked bulbs in different houses of the time. From top to bottom: Maison La Roche, 1923 / Maison Ozenfant 1924 / Maison Planeix, 1927. Source: L'Architecture vivante, París, autumn 1926: spring 1925 and spring 1930 
rendimientos nada tuvieran que ver con los arquitectos, sino que más con los técnicos contratados en cada caso. En 1929, Le Corbusier hizo la siguiente aclaración al presidente del Centrosoyuz de Moscú: "Nosotros jamás realizamos los planos de calefacción, agua, electricidad, (...) indicamos los lugares que requieren calefacción, agua, gas, (...) fijamos con el constructor los lugares por donde pasarán las canalizaciones de tal manera que resulte económico y que la arquitectura no se vea comprometida." Así, si el trabajo técnico era realizado por los constructores, entonces la selección y diseño de los artefactos para iluminar eran el centro de su preocupación para iluminar artificialmente. De esta manera la luz artificial jugaba entre la cruda luz de los artefactos desnudos -a veces incandescente y otras fluorescentes- y la sofisticada iluminación indirecta de complejas lámparas especialmente diseñadas. LOS OBJETOS COMO CENTRO DEL PROBLEMA DE LA LUUMINACIÓN / Beatriz Colomina (1991) ha mostrado consistentemente la importancia asignada por Le Corbusier a los objetos manufacturados industrialmente. Fue un coleccionista de catálogos y recortes de automóviles, aviones, muebles e incluso de turbinas y motores. Esta fijación no se limitó al hallazgo, fue un asiduo buscador que pedía a los fabricantes sus catálogos porque encontraba en ellos los argumentos para mostrar los aspectos más concretos de la sociedad maquinista ante los ojos de artistas, intelectuales y arquitectos. Los distintos artículos publicados en L'Esprit Nouveau están llenos de estos insumos. Esta fijación en los objetos comparece de forma evidente en su trabajo de la luz; sin embargo, no se trataba de disponer escenarios estáticos para iluminar objetos a la manera de una exposición, sino de ponerlos en juego como parte de la composición del espacio y utilizarlos para remarcar la libertad compositiva abierta por las estructuras de acero y hormigón armado.

La desnudez de las ampolletas y su cruda luz incandescente -objetos para iluminar- y la estratégica utilización de los antepechos -para iluminar los objetos- son algunas de las reglas que transformaron la iluminación en aquello que Le Corbusier llamó un juego sabio, que no es otra cosa que aquello que más adelante baitizó como su búsqueda paciente. ARa

\section{Bibliografía}

Banham, Reyner. "Máquinas para habitar". La arquitectura del entorno bien climatizado. Infinito, Buenos Aires, 1975, or. 1969. / Benton, Tim. "Villa La Roche and Jeanneret Raaf”. The villas of Le Corbusier and Pierre Jeanneret. 1920-1930. Birkhäuser, Basel-Boston-Berlin, 2007, or. 1987. / Bolstorff, H. "Alumbrado”. Academia Hütte de Berlín. Manual del Ingeniero II. Editorial Gustavo Gili, Barcelona, 1926. / Colomina, Beatriz. "Le Corbusier and Duchamp: the uneasy status of the object”. Mäkelä, Taisto y Wallis Miller (Eds.). Wars of classification. Architecture and Modernity. Princeton Architectural Press, Nueva York, 1991. / De Smet, Catherine. Vers une architecture du libre. Le Corbusier: édition et mise en pages 1912-1965. Lars Müller Publishers, Switzerland, 2007. / Le Corbusier. Almanach d' architecture moderne. Crés, París, 1925. / Le Corbusier. “Carta a Lubomov, 31 de enero de 1939”. Quetglas, Josep. Les heures claires. Proyecto y arquitectura de la Villa Savoye de Le Corbusier y Perre Jeanneret. Massilia, Barcelona, 2008. / Le Corbusier "Tres advertencias a los señores arquitectos. I El volumen" y "Arquitectura II. La ilusión de los planes”. Hacia una arquitectura. Apóstrofe, Barcelona, 1998, or. 1920. / Samuel, Flora. "Light and dark”. Le Corbusier in detail. Elsevier, Architectural Press, Oxford, 2007. following declaration to the president of the Centrosoyuz of Moscow: “(..) we never draw the heating, water and electrical plans, (...) we indicate the places that requite heating, water, light (...) we decided these places with the builder where the ducts will pass in way that is both economical and in which the architecture is uncompromised..." If the technical work was done by the builders, then the selection and design of the artifacts for illumination were center of his preoccupation with artificial lighting. In this way, the artificial light played between the crude light of the naked artifacts -sometimes incandescent and others fluorescent- and the sophisticated indirect lighting of complex, speciallydesigned lamps.

THE OBJECTS AS THE HEART OF THE PROBLEM OF ILLUMinAtion / Beatriz Colomina (1991) has consistently showed the importance assigned by Le Corbusier to industrially manufactured objects. He was a collector of catalogues and cut-outs of cars, planes furniture and even turbines and motors. This fixation was not limited to discovery, it was an assiduous search sought out manufacturers for their catalogues because in them he found the arguments for showing the most concrete aspects of the machinist society before the eyes of artists, intellectuals and architects. The various articles published in L'Esprit Nouveau are full of these consumables. This fixation on the objects appears in his work with light, however it did not mean arranging static stages for illuminating objects like an exhibition but to put them in play as part of the composition of the space, using them only to emphasize the compositional freedom opened by the structures of steel and reinforced concrete.

The nakedness of the light bulbs and their raw, incandescent light -objects for illumination- and the strategic utilization of the ledges -for illuminating the objects- are some of the rules that transformed illumination to that which Le Corbusier named a learned game, that is none other than that which he later called his patient search. ARQ

\section{Bibliography}

Banham, Reyner. "Máquinas para habitar". La arquitectura del entorno bien climatizado. Infinito, Buenos Aires, 1975, or. 1969. / Benton, Tim. "Villa La Roche and Jeanneret Raaf". The villas of Le Corbusier and Pierre Jeanneret. 1920 - 1930. Birkhäuser, Basel - Boston - Berlin, 2007, or. 1987. / Bolstorff, H. “Alumbrado”. Academia Hütte de Berlín. Manual del Ingeniero II. Editorial Gustavo Gili, Barcelona, 1926. / Colomina, Beatriz. "Le Corbusier and Duchamp: the uneasy status of the object". Mäkelä, Taisto y Wallis Miller (Eds.). Wars of classification. Architecture and Modernity. Princeton Architectural Press, New York, 1991. / De Smet, Catherine. Vers une architecture du libre. Le Corbusier: édition et mise en pages 1912-1965. Lars Müller Publishers, Switzerland, 2007. / Le Corbusier. Almanach d'architecture moderne. Crés, Paris, 1925. / Le Corbusier. "Carta a Lubomov, 31 de enero de 1939”. Quetglas, Josep. Les heures claires. Proyecto y arquitectura de la Villa Savoye de Le Corbusier y Perre Jeanneret. Massilia, Barcelona, 2008. / Le Corbusier "Tres advertencias a los señores arquitectos. I El volumen" y "Arquitectura II. La ilusión de los planes”. Hacia una arquitectura. Apóstrofe, Barcelona, 1998, or. 1920. / Samuel, Flora. "Light and dark". Le Corbusieindetail. Elsevier, Architectural Press, Oxford, 2007. 

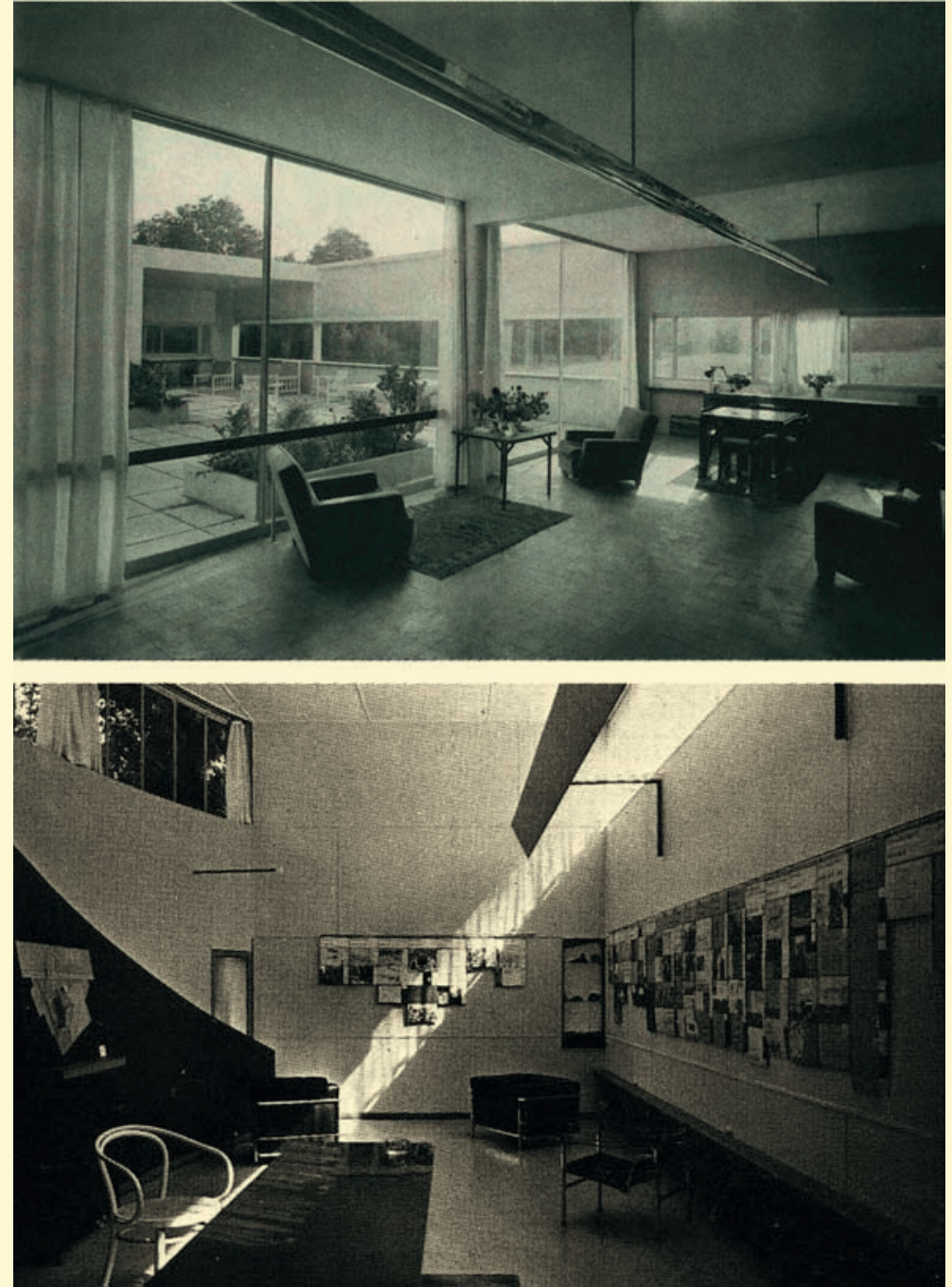

10 Lámparas de iluminación indirecta. Villas Savoye (arriba) y La Roche (abajo). Fuente: L'Architecture vivante, París, otoño, 1931. I Jencks, Charles. Le Corbusier and the tragic view of architecture. Harvard University Press, Cambridge-Mass, 1973

10 Lamps for indirect illumination of the Villas Savoye (above) and La Roche (below) autumn: $L^{\prime}$ Architecture vivante, París, autumn, 1931. / Jencks, Charles. Le Corbusier and the tragic view of architecture. Harvard University Press, Cambridge-Mass, 1973
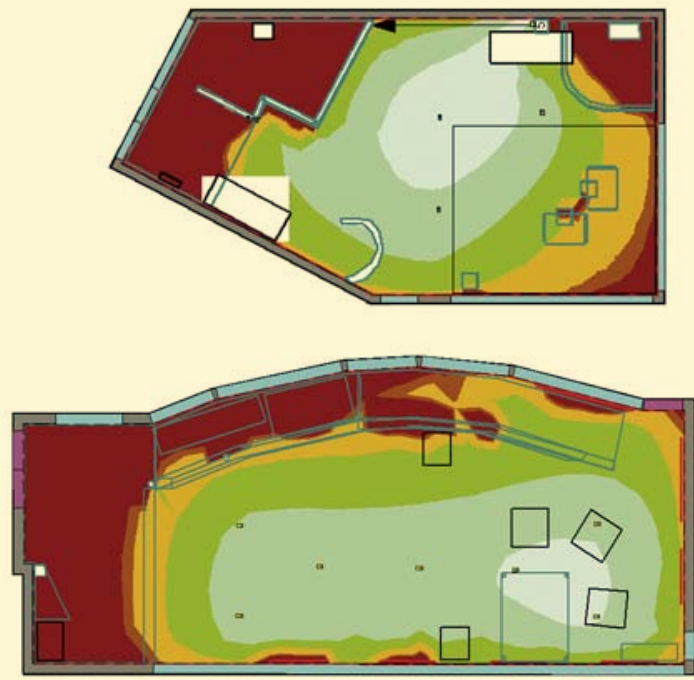

Intensidad luminica $(\mathbf{l x}$

11 Gráficos de niveles de iluminación Maison Ozenfant y Maison La Roche.

Fuente: Estudio realizado por Ignacio Pérez Piña con software relux, 2006

11 Graphics of illumination levels Maison Ozenfant y Maison La Roche

Source: Study realized by Ignacio Pérez Piña with software RELUX ${ }^{\circledR}, 2006$ 